\title{
The Brown Bear in Poland: its History and Present Numbers
}

\author{
Zbigniew JAKUBIEC \& Tadeusz BUCHALCZYK
}

Jakubiec Z. \& Buchalczyk T., 1987: The brown bear in Poland: its history and present numbers. Acta theriol., 32, 17: 289-306 [With 4 Tables \& 2 Figs.]

The brown bear, Ursus arctos Linnaeus, 1758 was exterminated all over lowland Poland and in Sudety Mts. remaining only in Carpathian Mts. where its range declined further till the World War I period. A small population survived within some isolated sites and started to grow again after the World War II with its territorial expansion markedly accelerated since the seventies. The number of brown bears in Poland increased 4-5 times within 1945-1982 period. The population number in 1982 was estimated at $70-75$ individuals. In early eighties four permanent refuges were known within Polish Carpathian Mts.: Żywiecki and Wysoki Beskid, Tatra Mts., Sądecki Beskid, and Bieszczady Mts. Most of the dens were found within these four refuges. The reproduction of brown bears is restricted to their permanent refuges. The estimated number of young for 1980-1982 period stood at $12-14$ (with average of 1.4 cubs per female).

[Nature Protection Research Centre, Polish Academy of Sciences, Podwale 75, 50-449 Wroclaw 2 (Z.J.) and Mammals Research Institute, Polish Academy of Sciences, 17-230 Białowieża (T.B.), Poland]

\section{THE AIM OF THE STUDY AND THE MATERIAL USED}

The aim of this study was to review tentatively the body of knowledge of the history of the brown bear (Ursus arctos Linnaeus, 1758) in Poland, its reproduction, population dynamics, and also to assess critically the principles of its protection applied so far.

The material comprised returns of three questionnaires sent to forest districts in Carpathian Mts., and to selected national parks. The surveys were carried out in 1963 and 1976 by the Mammals Research Institute at Białowieża, and the 1982 survey by the Nature Conservation Research Centre, both of Polish Academy of Sciences. The questionnaires of 1982 survey were supplemented by correspondence with many respondents. The questionnaires of 1965 survey pertained to all Carnivora while those in 1976 and 1982 dealt only with brown bears. The returing rate of two last surveys reached almost $100 \%$.

Any survey by questionnaires bears a certain error which is difficult to assess especially when the species under consideration is as rare and migrating as the brown bear is. The sources published in Poland so far, 
apart from a report by Buchalczyk (1980), does not include any comprehensive study on the species. Therefore, in spite of obvious shortcomings of a questionnaire-based study we decided to publish its outcome.

\section{RESULTS}

\subsection{The Brown Bear in Poland Before the Turn of the 19th Century}

The brown bear has once occurred throughout Poland. It was a popular game animal hunted for its meat and skin, although as early as in the 12th century bear hunting became an exclusive privilege of Polish monarchs as reported by Vincent "Kadłubek" in his chronicle written in 1202. This rule was not strictly observed and bears become rarer as a result of extermination. By the 17th century bears were quite rare in many provinces of Poland. This may be inferred from notes describing cases of killing bears as extraordinary events (Moszyński, 1939). The information about exterminating last individuals in lowland Poland dated from 18th century. Thus, last bears vanished from various parts of Pomerania within 1733-1772 period, from Bydgoszcz Province in 1789, from East Prussia in years 1727-1747, while from Romincka, Borecka, and Piska Forests - in 1788, 1800, and 1804 respectively (Fengewisch, 1965). In the "Polish Kingdom" established after 1812) the brown bears must have been rare indeed since some reports from 1830 mentioned a complete extinction of bears from its territory except in Białowieża Forest (Kobylański, 1939). In the former Eódzka Forest, at Radom, bears were killed as late as in 1867 (Kosman, 1934) while the last bear in Kielce Province was killed between 1828 and 1830 (Sztolcman, 1918). Surdacki (1977/78) reported that last bears within Lublin province had been killed at the turn of the 17th century. Also in the lowland part of Silesia, the last bears were killed in forests north of Opole in 1715-1750 (Pax, 1921; Simon, 1927), and near Lwówek Śląski - in 1726-1736 (Fengewisch, 1963). The last refuge of bears in lowland Poland was that of Białowieża but again here the last individuals were killed in 1873-1878 (Karpiński, 1949). Also in Sudety Mts., bears were exterminated before the end of the 18th century. The landlords in Kłodzko paid rewards for killed bears; the last bear there was killed in 1664 (Muszyński, 1939). The bears survived somewhat longer in the western part of Sudety Mts. In the Polish slopes of Karkonosze Mts. bears were hunted till 1756, and last tracks were reported in 1777 while on the Czech side of the border, the last bears were killed at the beginning of the 19th century (Stec, 1963). In the Izerskie Mts. bears were hunted till 1783 (Stec, 1963). The most prolonged period of bear hunting is reported from 
Jeseniki mountain range, but this involved animals migrating from Carpathian Mts. (Pax, 1921).

Thus at the end of the 19th century Carpathian Ivits. remained the only refuge for bears in Poland. By that time they still inhabited a significant range within this region. In the Żywiecki Beskid Mts. bears were hunted throughout that time and were regarded as pests killing of which was financially awarded (Augustynowicz, 1939; De Levaux, 1851; Kawecki, 1939). The numbers of bear decreased eg. in the forests of Żywiec estate despite efforts and rewards only two bears were killed. in 1877-1928 period (Lasy dóbr żywieckich, 1929). Nowicki (1870) reports on bears in Babia Góra Mt. region. The above information indicate that at the end of 19th century in the West Beskids and Babia Góra mountain ranges bears were encountered only as single, migrating individuals. In Tatra Mts., on the Polish side of the border, 1-2 bears were killed almost every year (Barabasz, 1929; Marchlewski 1962), and a 1879 census gave a total population figure of 15 bears for the whole of Tatra (Wrześniowski, 1882). Bear hunting in Bieszczady Mts. was reported by Leszczyński (1879), Schramm (1958) and Wohner (1880).

By the end of the 19th century brown bears were exterminated all over lowland Poland and in Sudety Mts., they survived only in Carpathians.

\subsection{The Brown Bear in Poland between 1900 and 1945}

Till the World War I brown bears were hunted in Tatra Mts. (Barabasz, 1929) and other regions of Carpathian Mts. In the museum at Żywiec there is an individual killed in 1908 at Okrajnik. The last migrating individuals at Sląski Beskid Mts. were observed around 1918 (F. Kotajny, pers. comm.). Babia Góra, Jałowiec, and Mądralowa mountain ranges remained the only places visited by bears; during the thirties at least two cases of bears sighted in the area were recorded (Kawecki, 1939; Parusel, 1983). Also in Tatra Mts., after the World War I, the number of encounters with bears dropped (Podobiński, 1961a, b) although bears have always been present there (Anonymus 1977; Domaniewski, 1930, 1931; Marchlewski, 1962; Nyka 1956). Detailed information from Bieszczady Mts. is not available but bears have also been found there (Lindemann, 1956).

In 1937 an effort was made at restitution of the brown bear at Białowieża (Karpiński, 1917). It succeded and in the time of World War II there were 3 bears living in the wild while in $1947-4$ individuals were present in the area (Karpiński, 1947).

The 1900-1945 period signified further decline in numbers of bears and progressive shrinking of its range. 


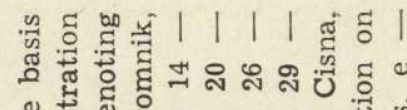

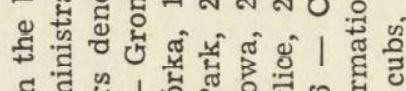
ธี قี

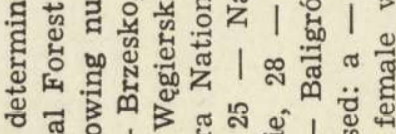
ช็ สี

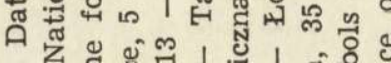
ง

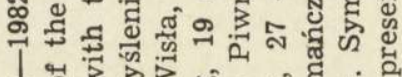

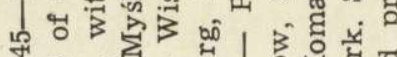

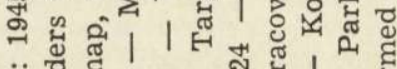

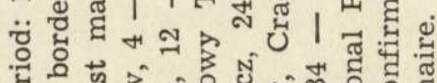

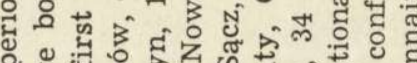

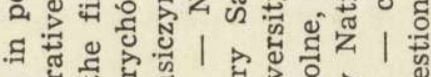

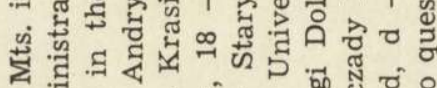

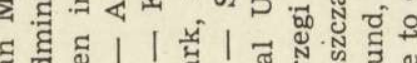

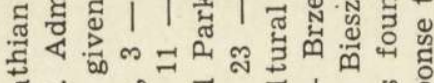

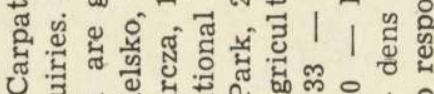
U。

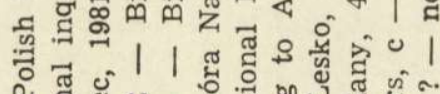

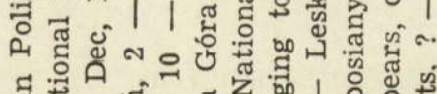

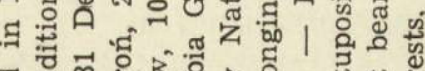
ซ

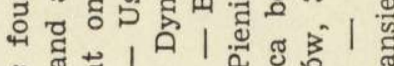
幽范।

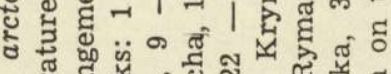
ธู สี

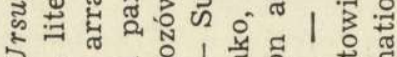

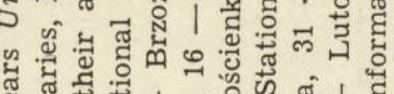

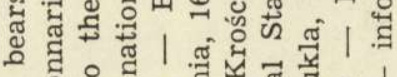

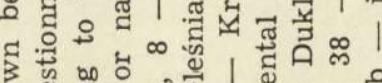

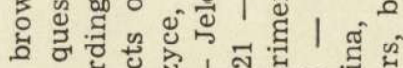
ช

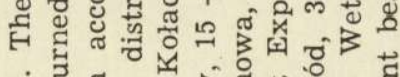
-

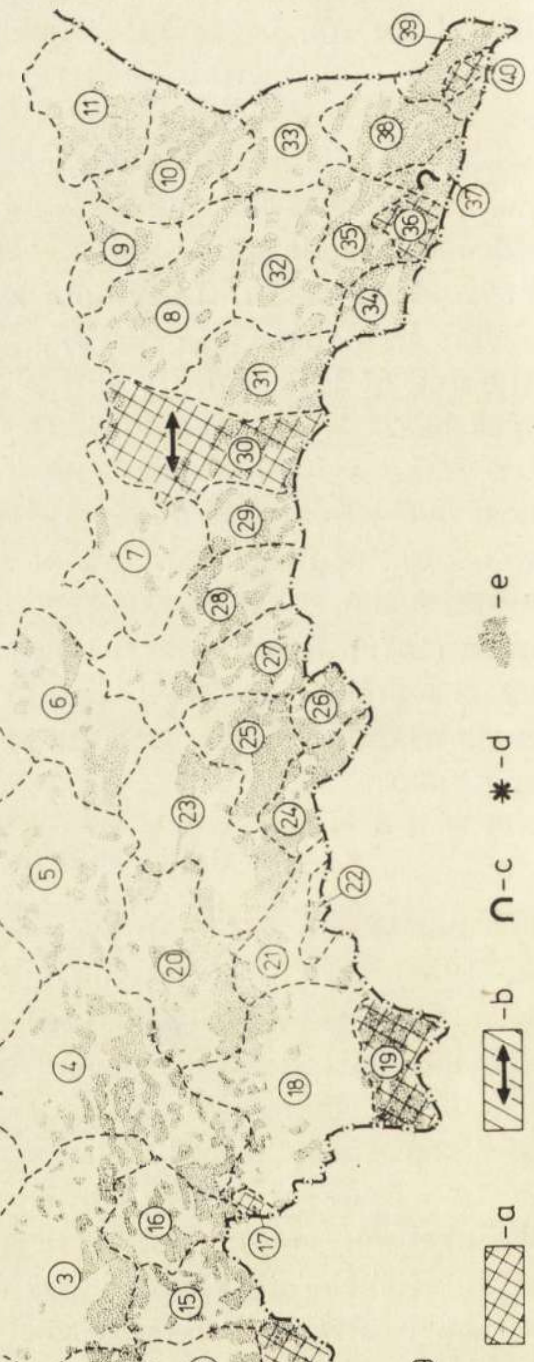

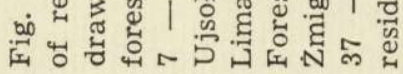



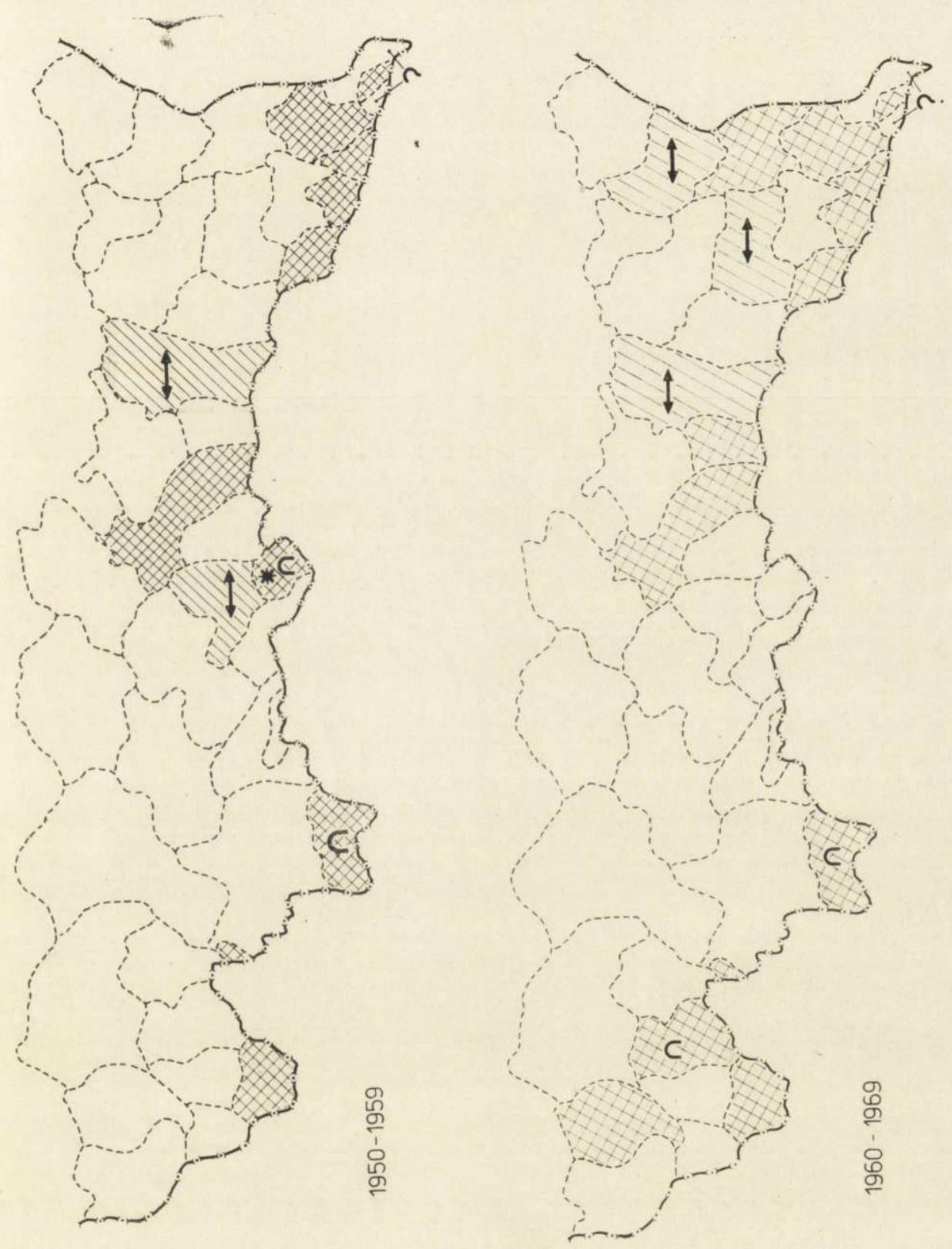

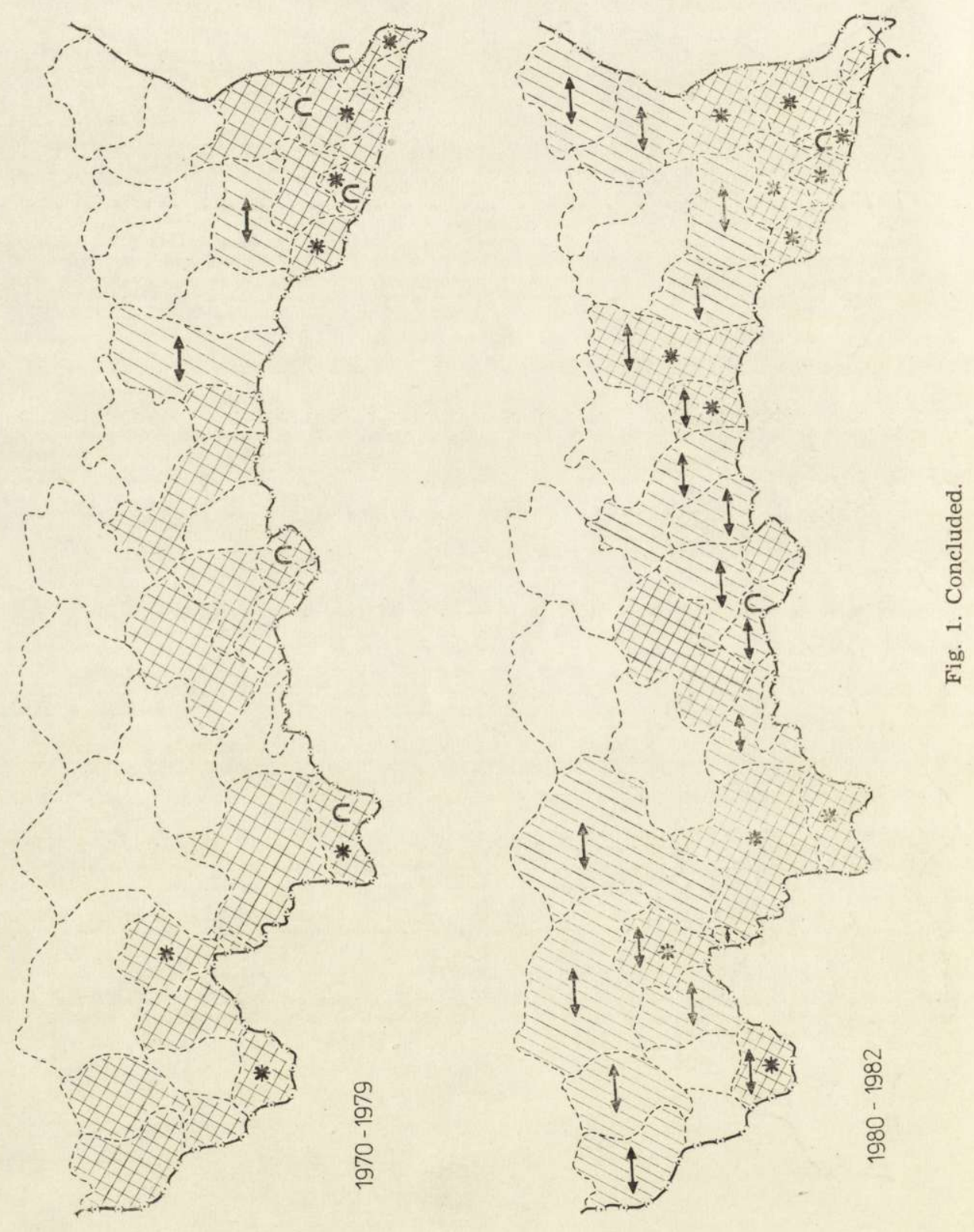


\subsection{The Brown Bear in Poland in 1946-1982}

In 1946, five bears were known to live in Białowieża Forest but owing to pouching (confirmed shooting of two individuals) this number dropped still further and in 1947 tracks were seen only once (Karpiński, 1947). Unconfirmed reports of bears hibernating in Lacka Forest (northwestern part of Białowieża Forest) in 1959/60 winter were obtained by K. Makush-Woronicz (pers. comm.). The presence of the last migrating individual was positively confirmed there in May 1963. The bear returned to the eastern part of forest after staying a mere couple of days (Buchalczyk. 1980).

The changes of distribution in Carpathian Mts. in 1946-1982 (Fig. 1) indicate that brown bears had been considerably expanding their range and in the beginning of the eighties were found in four permanent refuges: Żywiecki and Wysoki Beskid, Tatra Mts., Sądecki Beskid, and Bie-szczady Mts.

Table 1

Total numbers of the brown bear Ursus arctos in Poland.

\begin{tabular}{|c|c|c|c|c|}
\hline Year & Number & Reference & & \\
\hline 1946 & $10-14$ & Buchalczyk (1980) & & \\
\hline 1959 & $10-12$ & Fengewisch (1965) & & \\
\hline 1965 & $20-25$ & Questionnaire 1965, & corrected & data \\
\hline 1965 & 35 & Fengewisch (1965) & & \\
\hline 1970 & 36 & GUS (1975) & • & \\
\hline 1974 & 28 & GUS (1975) & & \\
\hline 1975 & 35 & Sumiński (1976) & & \\
\hline 1976 & $30-40$ & Questionnaire 1975 , & corrected & data \\
\hline 1982 & $70-75$ & Questionnaire 1982, & corrected & data \\
\hline
\end{tabular}

The Carpathian population was, for a long time, divided into two parts: - western, comprising Tatra Mts. and the mountain ranges west of it, and eastern - limited to western Bieszczady Mts. (Buchalczyk, 1980). Although some individuals migrating between these two parts had been reported earlier (Krygowski, 1963; Witowski, 1954), but actual merging took place after 1980 .

The territorial expansion of brown bears in Carpathian Mts. was by no means a steady process. Till the late sixties, the expansion was slow and restricted mainly to Bieszczady and Sląski Beskid Mts. After 1970 the expansion accelerated, chiefly in the western part of range: Sląski, Żywiecki and Wysoki Beskid Mts., as supported by data obtained by Parusel (1983) in Babia Góra massif.

Recently the range of brown bears in Poland covers southern part of 
Table 2

The results of questionnaire-based studies carried in 1965, 1976, 1982 on numbers of brown bears Ursus arctos L. in Polish Carpathian Mts.

\begin{tabular}{|c|c|c|c|c|c|c|c|c|c|}
\hline \multirow{2}{*}{$\begin{array}{l}\text { Forest } \\
\text { Administ. } \\
\text { District }{ }^{1} \\
\text { or National } \\
\text { Park }\end{array}$} & \multirow{2}{*}{$\begin{array}{c}1965 \\
\text { No. of } \\
\text { animals }\end{array}$} & \multicolumn{4}{|c|}{1976} & \multicolumn{4}{|c|}{1982} \\
\hline & & Adults & Cubs & Repr. ${ }^{2}$ & Uens & Adults & Cubs & Repr. $^{2}$ & Dens \\
\hline 1 & 2 & 3 & 4 & 5 & 6 & 7 & 8 & 9 & 10 \\
\hline \multicolumn{10}{|c|}{ Beskid Sląski Mts. } \\
\hline $\begin{array}{l}\text { Ustroń } \\
\text { (Brenna, Haźlach) }\end{array}$ & - & - & - & - & - & $1 \mathrm{M}$ & 1 & - & - \\
\hline $\begin{array}{l}\text { Bielsko-Biała } \\
\text { (Szczyrk, } \\
\text { Wapiennica) }\end{array}$ & $1 \mathrm{M}$ & $1 \mathrm{M}$ & 0 & - & + & $1 \mathrm{M}$ & 0 & - & - \\
\hline Wisła (Istebna) & - & $1 \mathrm{M}$ & 0 & - & - & - & - & - & - \\
\hline & & Beskid Z & Żywiecki & ki and $\mathrm{W}$ & Wysoki & Mts. & & & \\
\hline Ujsoly (Rycerka) & $+\mathbf{M}$ & $2 \mathrm{R}$ & 0 & - & - & $3 \mathrm{R}$ & 1 & + & - \\
\hline $\begin{array}{l}\text { Wégierska } \\
\text { Górka (Lipowa) }\end{array}$ & - & - & - & - & - & - & - & - & - \\
\hline Jeleśnia (Zywiec) & $+\mathrm{M}$ & $1 \mathrm{R}$ & 0 & - & - & $4 \mathrm{M}$ & 0 & - & - \\
\hline Sucha & - & - & - & - & - & $1 \mathrm{R}$ & 2 & + & + \\
\hline Andrychów & $\overline{v \pi}$ & - & - & - & - & $1 \mathrm{M}$ & 0 & - & - \\
\hline $\begin{array}{l}\text { Babia Góra } \\
\text { Ntl. Park }\end{array}$ & $+\mathrm{M}$ & $1-2 R$ & 0 & - & $?$ & $1 \mathrm{M}$ & 0 & - & - \\
\hline $\begin{array}{l}\text { Tatry } \\
\text { Ntl. Park }\end{array}$ & $6-8 \mathrm{R}$ & $7 \mathrm{R}$ & $\begin{array}{c}\text { Tatr } \\
1\end{array}$ & $\begin{array}{c}\text { ra Mts. } \\
+\end{array}$ & + & $6 \mathrm{R}$ & $?$ & + & t \\
\hline \multicolumn{10}{|c|}{ Beskid $\mathrm{S}$} \\
\hline Nowy Targ & $?$ & - & - & - & - & $2 \mathrm{R}$ & 1 & + & - \\
\hline Krościenko & ? & - & - & - & - & - & - & - & - \\
\hline $\begin{array}{l}\text { Pieniny } \\
\text { Ntl. Park }\end{array}$ & - & - & - & - & - & - & - & - & - \\
\hline $\begin{array}{l}\text { Limanowa } \\
\text { (Kamienica, } \\
\text { Poręba Wlk.) }\end{array}$ & - & - & - & - & - & - & - & - & - \\
\hline Stary Sącz & $?$ & - & - & - & - & $2 \mathrm{R}$ & 0 & - & + \\
\hline $\begin{array}{l}\text { Piwniczna } \\
\text { (Rytro, Muszyna) }\end{array}$ & $+\mathrm{M}$ & $2 \mathrm{R}$ & 2 & + & + & $2 \mathrm{M}$ & 0 & - & + \\
\hline Nawojowa & $-\bar{M}$ & $+\mathrm{M}$ & - & - & - & $2 \mathrm{R}$ & 0 & - & - \\
\hline $\begin{array}{l}\text { Krynica } \\
\text { Exp. Stn. }\end{array}$ & $1 \mathrm{M}$ & - & - & - & - & $2 \mathrm{R}$ & 0 & - & - \\
\hline \multicolumn{10}{|c|}{ Beskid Niski Mts. } \\
\hline $\begin{array}{l}\text { Eosie (Snietnica, } \\
\text { Gładyszów) }\end{array}$ & $?$ & $1 \mathrm{MI}$ & 0 & - & - & $1 \mathrm{M}$ & 0 & - & - \\
\hline Gorlice (Gładyszów & w) ? & $1 \mathrm{M}$ & 0 & - & - & $1 \mathrm{M}$ & 0 & - & - \\
\hline Żmigród (Krempna & a) - & $1 \mathrm{M}$ & 0 & - & - & $1 \mathrm{M}$ & 0 & + & - \\
\hline Kołaczyce & $\bar{M}$ & $\bar{M}$ & - & - & - & $\bar{M}$ & - & - & - \\
\hline $\begin{array}{l}\text { Dukla (Krosno, } \\
\text { Jaśliska) }\end{array}$ & $+\mathrm{M}$ & $2 \mathrm{M}$ & 0 & - & - & $0 \mathrm{M}$ & 0 & + & - \\
\hline Rymanów & - & $?$ & & & $?$ & $1 \mathrm{R}$ & 0 & - & + \\
\hline \multicolumn{10}{|c|}{ West Bieszczady Mts. } \\
\hline Lesko (Zagórz) & $?$ & $1 \mathrm{M}$ & 0 & - & - & $1 \mathrm{M}$ & 0 & - & + \\
\hline $\begin{array}{l}\text { Bircza } \\
\text { Brzegi Dolne }\end{array}$ & $\stackrel{?}{-}$ & $2 \bar{M}$ & $\overline{0}$ & - & $\overline{-}$ & $1 \overline{\mathrm{R}}$ & $\overline{2}$ & $\bar{t}$ & $\bar{?}$ \\
\hline $\begin{array}{l}\text { Komańcza } \\
\text { (Łupków) }\end{array}$ & $+\mathrm{M}$ & $3 \mathrm{R}$ & 0 & - & - & $7 \mathrm{R}$ & 2 & + & -3 \\
\hline
\end{tabular}




\begin{tabular}{|c|c|c|c|c|c|c|c|c|c|}
\hline 1 & 2 & 3 & 4 & 5 & 6 & 7 & 8 & 9 & 10 \\
\hline $\begin{array}{l}\text { Baligród } \\
\text { (Bukowiec) }\end{array}$ & $?$ & $1 \mathrm{M}$ & 0 & - & - & $1 \mathrm{M}$ & 0 & - & - \\
\hline Cisna & $+\mathrm{M}$ & $1-2 \mathrm{R}$ & 0 & + & + & $3 \mathrm{R}$ & 0 & + & + \\
\hline Wetlina & $3 \mathrm{R}$ & $2 \mathrm{R}$ & 0 & - & - & $1 \mathrm{R}$ & 2 & + & + \\
\hline $\begin{array}{l}\text { Lutowiska } \\
\text { (Dwernik) }\end{array}$ & $2 \mathrm{R}$ & $6 \mathrm{R}$ & 2 & - & + & $7 \mathrm{R}$ & 5 & + & + \\
\hline $\begin{array}{l}\text { Bieszczady } \\
\text { Ntl. Park }\end{array}$ & & $2 \mathrm{M}$ & 0 & - & - & $4 \mathrm{R}$ & 0 & - & + \\
\hline $\begin{array}{l}\text { Stuposiany } \\
\text { (Tarnawa) }\end{array}$ & $+R$ & $6 \mathrm{R}$ & 一 & - & + & $?$ & $?$ & $?$ & ? \\
\hline Total & $13-15$ & $44-46$ & 6 & (3) & (6) & 57 & 16 & (12) & $(10)$ \\
\hline
\end{tabular}

1 According to Polish state forests dividing of 1982. Earlier smaler district names are given in brackets. ${ }^{2}$ Repr. - reproduction, + - occured, - - not informed Explanation of symbols: + - presence, - . no data, ? - no response to questionnaire, $\mathrm{R}$ - resident, $\mathrm{M}$ - migrating.

Table 3

The numbers of the brown bear Ursus arctos in West Bieszczady Mts.

\begin{tabular}{rrl}
\hline Year & \multicolumn{1}{c}{ Number } & \multicolumn{1}{c}{ References } \\
\hline c. 1950 & several $(<10)$ & Grodziński (1957) \\
1958 & several $(<10)$ & Ogonowski (1958) \\
1962 & $12-14(\max .17)$ & Bielewicz (1962) \\
c. 1963 & $25 \quad$ ? & Kosiba (1964) \\
1968 & c. 20 & Glowaciński \& Witkowski (1969) \\
1972 & c. 25 & Ogonowski (1972) \\
& $25-31$ & Buchalczyk \& Markowski (1979) \\
1973 & 30 & Ogonowski (1973) \\
1976 & 25 & Sumiński (1976) \\
1976 & $18-27$ & Garstka (1977) \\
1982 & 44 & Buchalczyk (1980) \\
& & Questionnaire, 1982 \\
\hline
\end{tabular}

western Beskidy Mts. and western part of Nowy Targ Valley, Tatra Mts., southern ranges of Eastern Beskidy Mts., and the whole area of Bieszczady Mts. (Buchalczyk, 1983).

\subsection{The Numbers of the Brown Bear in Poland in 1946-1982}

Tł.e data on estimated total numbers of bears in Poland since 1946 are presented in Table 1. The figures for 1970 and 1974 are undoubtedly overestimated as the official statistical data do not allow corrections for migration. The overall estimates for the $1946-1982$ stands at $25-30$ animals.

The results of questionnaire--based surveys carried out in 1965, 1976 and 1982 are given in Table 2. In 1965 13-15 bears were reported. 
Taking into account large number of questionnaires returned without numbers of bears specified and a number of bears that might be migrating, the total count could be estimated at 20-25 individuals. In 1976 the survey gave estimate of $44-46$ adults and 6 one-year old cubs. Again thes s data are too high because of interpolation has been made for three

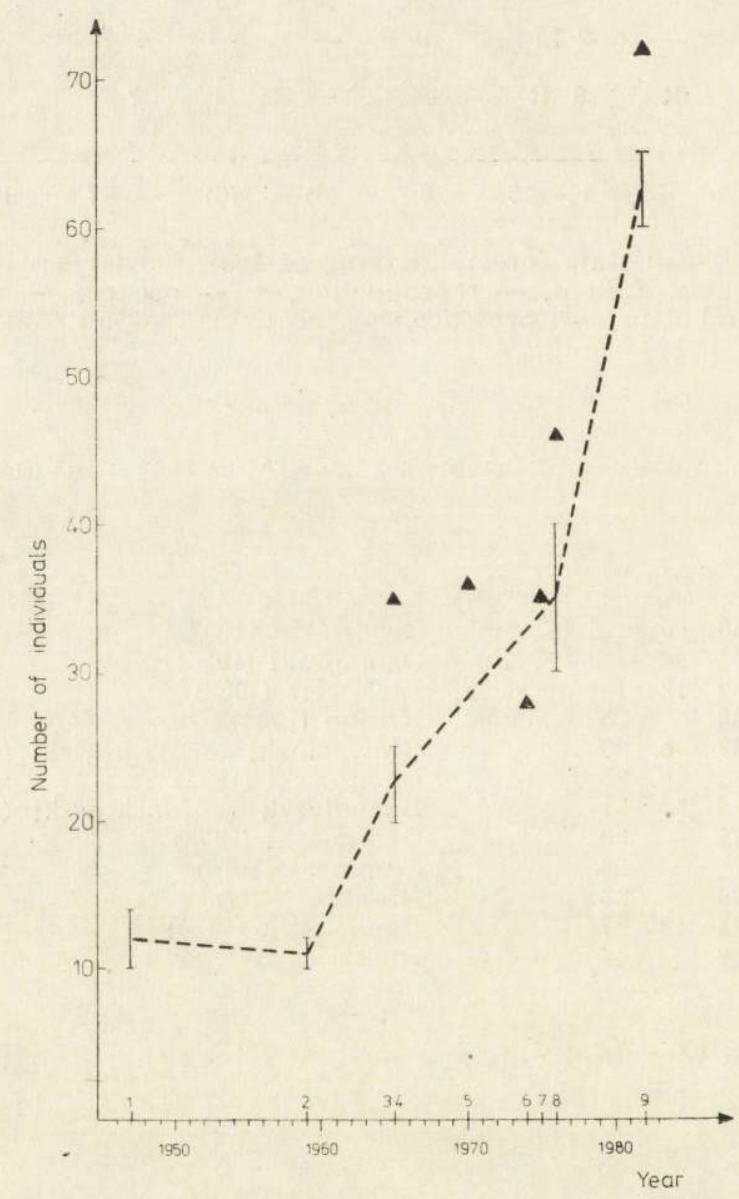

Fig. 2. Changes in numbers of brown bears (Ursus arctos) in Poland in 1946-1982 period. Labels 1 to 9 correspond with items in Table 1 . Triangles denote maximum values. Vertical lines represent observed ranges.

years and no correction for migrating individuals introduced. The overall number of bears in Poland could be than estimated at 30-40 individuals The 1982 survey and additional inquiries revealed 57 adults and 16 cubs i.e. lotal of 73 bears. Taking into account lacking returns from Stuposiany forest district (at least 10 bears) and certain overestimate owing to migration, the total count can be assessed as $70-75$ animals. The changes 
in numbers in 1946-82 (Fig. 2) indicate that there was four to fivefold incruase of the bear population within this period.

In the two main refuges in Poland: Bieszczady and Tatra Mts., the dynamics of bear populations are similar (Table 3). In Bieszczady, during the first twenty years the numbers increased slowly to gain a significant momentum after 1970. In the Polish part of Tatra, according to the data gathered by Chałupczyńska (in prep.) again the number of bears prior to 1960 rose to their usual number of $7-10$ individuals and maintained it, with certain oscillation, throughout the following period. The alterations in numbers depend on migrations to the southern and northern slopes and on limited capacity of Tatra habitats. Such carrying capacity was estimated as early as in the last century (Marchlewski, 1962). Simultaneously, in the Babia Góra massif the number of bears increased as shown by Parusel (1983).

\subsection{Reproduction}

Table 4 shows that in 1953-1982 in Poland (except Tatra Mts.) 27 bears were observed with 41 cubs. The number of females with cubs varied e.g. in $1980-7+10$ cubs; in $1981-3+4$; in $1982-11+16$, i.e. annual average of 10 cubs. The annual increase for year 1982 amounted to $21.9 \%$ but in comparison to both preceding years it was an exceptionally good year. If the annual increase is calculated on the basis of the average population numbers the value rises still further to $23.9 \%$. Usually, the number of cubs per female was one or two (in 14 and 12 cases respectively) only twice the females were reported to move about with three cubs one by Podobinski (1959) from Tatra, the other from Lutowiska forest district in 1982 (J. Moszyńska, in litt.). The complete set of data for 1953-1982 period gives an average of 1.5 cubs per female, while for $1980-1982$ period -1.4 cubs.

Chałupczyńska (in press) has summarized all the data on the brown bear reproduction in Polish Tatra Mts. and reported that in 1943-1980 period 24 females with 46 cubs were sighted there i.e. the number of cubs per female was 1.9. On the Slowak part of Tatra the average was 1.6 in 1943-1971 (Podobiński, 1974).

Normally, in Tatra, $1-2$ females give birth to cubs while in the whole of Polish Carpathian Mts. (Tatra included) 12-14 cubs are born every year.

However, there is no information about cub mortality in the first year of life and later before reaching maturity. The only bit of information was provided by Parusel (1982) who reported a finding of a dead cub 
in the Babia Góra region. There are some notes about young bears $(2-3$ year old) killed at various localities (Bunsch 1967; Jakubiec et al., 1983; Leńkowa, 1966; Parusel, 1982; Sałyga-Dąbrowska, 1980).

Table 4

Cases of reproduction observed in brown bear Ursus arctos in Poland (except in Tatra Mts.).

\begin{tabular}{|c|c|c|c|}
\hline Year & Locality ${ }^{1}$ & $\begin{array}{c}\text { No of } \\
\text { females +young }\end{array}$ & References \\
\hline 1953 & Beskid Sądecki (Jaworzyna) & $1+2$ & Czarnowski (1955) \\
\hline 1966 & Muszyna & $1+2$ & Questionnaire, 1976 \\
\hline 1976 & Stuposiany & $1+1$ & \\
\hline \multirow[t]{3}{*}{1979} & Babia Góra northern slopes & $1+2$ & Tomek (1983) \\
\hline & Sucha, range Jałowiec & $1+2$ & Parusel (1983) \\
\hline & Ujsoly, Zwardoń & $1+2$ & \\
\hline \multirow{7}{*}{1980} & Ujsoły & $1+1$ & Questionnaire, 1982 \\
\hline & Piwniczna & $1+2$ & M. W. Witkowski \\
\hline & Żmigród & $1+2$ & Questionnaire, 1982 \\
\hline & Dukla & $1+1$ & $"$ \\
\hline & Komańcza & $1+1$ & ", \\
\hline & Cisna & $1+1$ & " \\
\hline & Brzegi Dolne & $1+2$ & 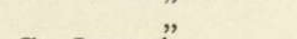 \\
\hline \multirow[t]{3}{*}{1981} & Ujsoly - Glinka & $1+2$ & Cz. Iwanek \\
\hline & Sucha & $1+1$ & Questionnaire, 1982 \\
\hline & Komańcza & $1+1$ & \\
\hline \multirow[t]{9}{*}{1982} & Ustroń & $1+1$ & S. Janczar \\
\hline & Ujsoly & $1+1$ & Questionnaire, 1982 \\
\hline & Babia Góra National Park & $1+2$ & „, \\
\hline & Nowy Targ & $1+1$ & $"$ \\
\hline & Komańcza & $2+2$ & " \\
\hline & Brzegi Dolne & $1+2$ & $"$ \\
\hline & Lutowiska & $3+5$ & " \\
\hline & Wetlina & $1+2$ & $"$ \\
\hline & Total & $27+41$ & \\
\hline
\end{tabular}

${ }^{1}$ Names are given of mountains, national parks and State Forest Administration Districts.

\subsection{Information About Dens and Hibernating Bears}

In all, the information has been collected about 19 dens (Fig. 1). Although reflecting rather accindental findings they indicate that den sites are restricted mainly to the permanent refuges (see also Kowalski, 1962; Tomek, 1983).

Czarnowski (1955) informed about the den found in Sądecki Beskid in 1953. The data on den found on slopes of Szyndzielnia Mt. during 1966/67 and 1967/68 were given by F. Kotajny (in litt.). Account of den on Wołoszyn slopes was given by Nyka (1955) and on Czuba Rostocka by Podobiński (1959). Kowalski (1962) mentioned dens in caves of Mała Łąka Valley. From Jeleśn forest district, a detailed description was 
obtained of half-completed den found by S. Majer. It was situated under a large rock with windfallen tree leaning on it. It was lined with moss and stone pine (Pinus cembra) branches (there was a stone pine plantatior. nearby). Inside about half bucket of mountain ash, briar rose fruits and sloe-plums was found. Each kind of fruit was stored on a separate heap. In Bieszczady Mts., a den was found during 1961/62 winter within a tree belt in the fields, close to a village and in a large distance from forest (Bielewicz, 1962).

Every year, some bears do not enter winter sleep (Ogonowski, 1972). Under the climatic conditions prevailing in Poland the individuals active in January and February should be regarded as those that did not sleep (or were awakened).

\section{DISCUSSION}

Man exterminated bears throughout the ages because of overlapping ecological niches (oat, wild fruits, honey, domestic and game animals). Killing the remaining individuals in Poland between 17th and 19th centuries was a part of all-European drive although it was somewhat delayed (Fengewisch, 1963; Volmar, 1940).

During 1946-1982 in Polish Carpathian Mts. territorial expansion and increase in numbers of bears occurred. Both these processes gained momentum after 1970 and were undoubtedly linked with expansion of range and considerable numerical increase of the brown bear population in Slovakia (Hell, 1981; Macko, 1972; Randik, 1971). Similar expansion has also been observed in Finland (Pulliainen, 1983). A rebounce in bear numbers in local Europear. populations may be explained by protective measures introduced there or by a rational management of bear populations.

The average number of cubs per female in Poland stands at $1.4-$ a value which is rather low when compared with corresponding data obtained in North America (Martinka, 1974; Pearson, 1975), and in Northern Europe (Novikov et al., 1969).

In the years $1980-1982$ considered in this study there were considerable oscillations in numbers of females with cubs. These stem from multiannual reproduction cycle in bears (Mundy \& Flook, 1973) and from small size of Polish population. Similar phenomena were found by Martinka (1974) in his studies on much larger population of the grizzly bear.

The calculated annual increment in Polish population reached $21.9 \%$ in an particularly good year 1982. The annual population increments given by other authors ranged, in North America, between 14 to $26 \%$ (Mundy \& Flook, 1973) or attained 19\%, as average for a five-year period 
(Martinka, 1974). In Slovak Tatra Mts. the increment ranged from 5 to 15\% (Randik, 1971). There are diverse opinions about the cub mortality in the first year of life. In contrast to Martinka (1974) and Pearson (1975), Mundy and Flook (1973), Novikov et al. (1969), and Randik (1971) point at significant mortality within the first year.

\section{KEY ISSUES IN BEAR PROTECTION}

The increase in population numbers and territorial expansion of brown bears has brought about more palpable increase in the level of damage caused by these animals (Dębski, 1971; Rozpara, 1984; Sola, 1973). The volume of the damage is not yet high but it increases every year. So far, killing the animals was the only preventive measure in case of damage caused by bears. At least six bears have been shot in Poland since the end of World War II (Jakubiec et al., 1983; Leńkowa, 1966; Olszewski, 1971; Parusel, 1982; and others). There have also been several cases of pouching. Around 1974 a bear got shot in Sądecki Beskid Mts.; in 1980 two animals were killed in forest districts of Sucha and Stary Sącz.

The compensation issue was regulated as early as in 1970 , by no means solving the problem of bear damage. It seems that the conditions of maintaining the bear population in Poland should be studied in deep and a general line of tackling the problems should be established. First suggestions are already there (Buchalczyk, 1980; Jakubiec et al., 1983; Padol, 1981; Parusel, 1982). It is the matter of utmost importance to carry out annual censuses (as accurate as possible) of bear population in Poland. A follow-up should include: identifying and securing bear refuges (e.g. by extending national parks), changes of tourist routes, setting up undisturbed and silence zones. Next important task is to educate the forest administration, local population and tourists in respect to right attitude to bear and its protection. It seems that there are prospects for introducing bears into new areas (e.g. Karkonosze Mts.), particularly because the density of human settlements in Carpathian Mts. makes supporting any greater number of bears impossible.

The suggested measures should be implemented in close cooperation with Slovak counterparts. It should be stressed that any delay in introducing active protection of bear may contribute to a rapid increase in damage caused by bears thus threatening a change in positive, public attitude towards the species observed till now.

Acknowledgements: The authors would like to thank warmly all the persons who answered their inquiries, and also those who additionally passed a lot of valuable information. 


\section{REFERENCES}

1. Anonymous (W. M.), 1977: Niedźwiedź w Tatrach. Ze starych kronik. Łow. polski, 17 (1548): 13 .

2. Augustynowicz W., 1939: Chrońmy przyrodę Żywiecczyzny. Gronie, 2, 1: 11-16.

3. Barabasz S., 1929: Niedźwiedź w Tatrach. Wierchy, 7: 1-29.

4. Bielewicz M., 1962: Wczoraj i dziś łowiectwa w Bieszczadach. Łow. pol., 23-24 (1194-1195): 2-5.

5. Buchalczyk T., 1980: The brown bear in Poland [In: "Bears - Their Biology and Management", C. J. Martinka and K. L. McArthur, eds.]. Bear Biol. Assoc. Conf., Ser., 3: 229-232. Kalispell.

6. Buchalczyk T., 1983: Ursus arctos Linnaeus, 1758. [In: "Atlas of Polish mammals". Z. Pucek \& J. Raczyński eds]. PWN - Polish Sci. Publ.: 139 and map No. 0065 on p. 133. Warszawa.

7. Buchalczyk T. \& Markowski J., 1979: Ssaki Bieszczadów Zachodnich [Mammals of the Western Bieszczady Mts.]. Ochrona Przyr., 42: 119-150.

8. Bunsch A., 1967: Jeden $\mathrm{z}$ ostatnich. Wierchy, 36: 266-267.

9. Chałupczyńska E., 1980: Niedźwiedź brunatny, Ursus arctos Linnaeus, 1758 na ziemiach polskich i w polskich ogrodach zoologicznych. MS Thesis, Agricultural Academy, Wrocław. [In Polish].

10. Czarnowski A., 1955: Rzadkie zwierzęta w Beskidzie Sądeckim. Wierchy, 25: 260.

11. De Laveaux L., 1851: Górale Beskidowi zachodniego pasma Karpat. Rys etnograficzny zwyczajów i obyczajów włościan okolic Żywca. Nakładem i drukiem J. Czecha: 1-153. Kraków.

12. Dębski J., 1971: Niedźwiedzie zagrażają hodowli zwierząt w Bieszczadach. Życie wet., $46,8: 254-256$.

13. Domaniewski J., 1930: Sprawozdanie $\mathrm{z}$ prac nad ochroną przyrody $\mathrm{w}$ Tatrach za czas od 1.IV.1927 do 1.X.1930. Ochrona Przyr., 10: 215-225.

14. Domaniewski J., 1931: Łowiectwo w Tatrach w latach 1927-1930. Łow. pol., 9: 10.

15. Fengewisch H. - J., 1965: Grossraubwild in Europas Reviren. BLW: 1-228. München, Basel, Wien.

16. Garstka K., 1977: Niedźwiedź w Bieszczadach. Przyr. pol., 9: 24.

17. Głowaciński Z. \& Witkołwski Z., 1969: Fauna Bieszczadów Zachodnich i zagadnienia jej ochrony. Ochrona Przyr., 34: 127-160.

18. Grodziński W., 1957: Materiały do fauny kręgowców Bieszczad Zachodnich. Zesz. nauk. UJ Zool., 10, 1: 177-221.

19. Hell P., 1981: Ochrana medveda na Slovensku. Polov. a Rybár., 33, 5: 7.

20. Jakubiec Z., Bieniek M. \& Profus P., 1983: Czy niedźwiedzie wrócą do swych dawnych ostoi? Las pol., 2(950): 27-29.

21. Karpiński J. J., 1947: Odrodzenie niedźwiedzia w Puszczy Białowieskiej. Manuscript: $1-29$. Białowieża.

22. Karpiński J. J., 1949: La régenération de l'ours dans la Forêt de Białowieża Bijdragen tot de Dierkunde, 28: 218-236.

23. Kawecki W., 1939: Lasy Żywiecczyzny, ich teraźniejszość i przeszłość. Prace rol.-leś. PAU, Nr 35: 1-172.

24. Kobylański J. W., 1939: Niedźwiedź mocarz puszcz naszych. Echa leśne, 15, 25: $571-572$.

25. Kosiba W., 1964: Niedźwiedzie w Bieszczadach. Łow. pol., 4 (1223): 3. 
26. Kosman E. O., 1934: Sladami dawnej Łodzi. Tow. Przyrodn, im. Staszica: 1-31. Łódź.

27. Kowalski K., 1962: Ssaki. [In: „Tatrzański Park Narodowy”. W. Szafer ed.]. Zakład Ochr. Przyr. PAN, Wyd. popul.-nauk., 21: 365-388. Kraków.

28. [Krygowski W.] x. y., 1963: Niedźwiedzie w Beskidzie Niskim. Wierchy, 31: 260.

29. Lasy dóbr żywieckich 1929. [opracował inż. W. Fucik]. Nakładem dyrekcji dóbr żywieckich w Żywcu: $1-48$.

30. Leńkowa A., 1966: W sprawie ochrony niedźwiedzia. Chrońmy Przyr. ojcz. 22, 4: $55-57$.

31. Leszczyński E., 1879: [Korespondencye z Samborskiego]. Łowiec, 2, 7-8: 108, $126-127$.

32. Lindemann W., 1956: Braunbären als Standwild im Niedrigen Beskid und in den Bieszczaden. Die Pirsch, 8, 8: 256.

33. Macko P., 1972: Medvede rozsiruju svoj areal. Polov. a Rybár., 13: 8.

34. Marchlewski M., 1962: Zwierzyna w Tatrzańskim Parku Narodowym. [In: „Tatrzański Park Narodowy", W. Szafer ed.]. Zakł. Ochr. Przyr. PAN, Wyd. popul.-nauk., 21: 523-546. Kraków.

35. Martinka C. J., 1974: Population characteristics of grizzly bears in Glacier National Park, Montana. J. Mammal., 55: 21-29.

36. Moszyński A., 1939: Fauna Dolnego Sląska. Wszechświat, 2: 37-42.

37. Mundy K. R. D. \& Flook D. R., 1973: Background for managing grizzly bears in the National Parks of Canada. Can. Wildl. Serv. Report Series, No. 22: $1-35$.

38. Novikov G. A., Airapetjants A. E., Pukinsky Yu. B., Timofeeva E. K. \& Fokin I. M., 1969: Some peculiarities of population of brown bears in the Leningrad district. Zool. Zhurn., 48, 6: 885-901. [In Russian with English summary].

39. Nowicki M., 1870: Zapiski faunistyczne. Spraw. Kom. Fizyograf., 4: 1-40.

40. Nyka J., 1955: Gawra na zboczu Wołoszyna. Wierchy, 24: 221.

41. Nyka J., 1956: Dolina Rybiego Potoku. Sport i Turystyka: 1-203. Warszawa.

42. Ogonowski T., 1958: Niedźwiedzie w Bieszczadach. Łow. pol., 2: 15.

43. Ogonowski T., 1972: Bieszczadzka mozaika. Łow. pol., 4 (1415): 14.

44. Ogonowski T., 1973: Bieszczadzkie nowiny. Łow. pol.,22 (1457): 9.

45. Olszewski J., 1971: To właśnie ten. Łow. pol., 3 (1390): 6-7.

46. Padoł J., 1981: Uwagi o ochronie niedźwiedzi brunatnych Ursus arctos i niektórych ptaków drapieżnych w Tatrzańskim Parku Narodowym. Chrońmy Przyr. ojcz., 37, 6: 40-43.

47. Parusel J. B., 1982: Przypadek zabicia niedźwiedzia brunatnego, Ursus arctos L. w masywie Policy a sprawa powiększenia Babiogórskiego Parku Narodowego. Chrońmy Przyr. ojcz., 38, 4-5: 71-73.

48. Parusel J. B., 1983: Obserwacje niedźwiedzia brunatnego Ursus arctos L. w paśmie Babiej Góry i okolicy. Parki Narodowe i Rezerwaty Przyrody, 4, 2: $75-82$.

49. Pax F., 1921: Die Tierwelt Schlesiens. G. Fischer Verlag: 1-342. Jena.

50. Pearson A. M., 1975: The northern interior grizzly bear, Ursus arctos L. Can. Wildl. Serv. Report Series, 34: 1-81.

51. Podobiński L., 1959: Kilka uwag o liczebności i wędrówkach niedźwiedzi tatrzańskich. Chrońmy Przyr. ojcz., 15, 4: 35-37.

52. Podobiński L., 1961a: Niedźwiedzie, rysie, wilki i orly w Tatrach. [In: „Paster- 
stwo Tatr Polskich i Podhala". T. 3. W. Antoniewicz ed.]. Ossolineum. 149-168. Wrocław-Kraków-Warszawa.

53. Podobiński L., 1961b: Zwierzyna tatrzańska w $1960 \mathrm{r}$. Wierchy, 30: 250-251

54. Podobiński L., 1974: Zwierzęta tatrzańskie w $1973 \mathrm{r}$. Wierchy, 43: 212-221.

55. Pulliainen E., 1983: Behaviour of an expanding population of the brown bear (Ursus arctos) in northern Europe. Z. Säugetierkunde, 48: 290-297.

56. Randik A., 1971: Razširenie a ochrana medveda hnedego (Ursus arctos) v Československu. Českoslov. Ochr. Prirody, 11: 231-256.

57. Rozpara G., 1984: Prawo a zwierzęta pod ochroną, które niszczą pasieki. Pszczelarstwo, 35, 3: 21-22.

58. Salyga-Dąbrowska K., 1980: Nazywano go Miś Kondracki. Wierchy, 49: 313-316.

59. Schramm W., 1958: Lasy i zwierzyna Gór Sanackich. Pozn. Tow. Przyj. Nauk. Wyd. popul-nauk., PWN: 1-111. Poznań.

60. Simon., 1927: Ausgestorbene Tiere der oberschlesien Fauna. Oberschlesier, 9, 6. $371-374$.

61. Sola S., 1973: Pszczelarze, niedźwiedzie i paragrafy. Pszczelarstwo, 24, 10: $16-17$.

62. Steć T., 1963: Sudeckie przyczynki. ... Niẹźwiedź w Sudetach. ... Wierchy, 32: $163-175$.

63. Sumiński P., 1976: Postavenie vel'kých mäsožravcov (Carnivora) v pol'ovnom hospodárstve Pol'skej L'udovej Republiky. Foli venatoria, 5-6: $351-362$.

64. Sztolcman J., 1918: Łowiectwo. Podręcznik dla szkół leśn. i roln. Wyd. Warszawskiego Tow. Prawidłowego Myślistwa. Druk „Gazety Rolniczej” (W. Musielewicza): $1-370+$ VI. Warszawa.

65. Surdacki S., 1977/1978: Zmiany w występowaniu i liczebnaści niektórych gatunków ssaków na obszarze byłego woj. lubelskiego w XIX i XX wieku. Annls. Uniw. Mariae Curie-Sklodowska, Sect. B. 22/23, 13: 315-335.

66. Tomek A., 1983: Niedźwiedzie Ursus arctos w Beskidach. Chrońmy Przyr. ojcz., 39, 4: 64-66.

67. Volmar F. A., 1940: Das Bärenbuch. Paul Kaupt: 1-404. Berno.

68. Witkowski M., 1954: Niedźwiedź w Beskidzie Sądeckim. Łow. pol., 1 (1021): 14.

69. Wohner L., 1880: Kronika z Wetliny z 20 września 1880. Łowiec, 3, 11: 175.

70. Wrześniowski A., 1882: Tatry i Podhale. Pam. Tow. Tatrz., 7: 10.

Received 5 March 1986, Accepted 1 April 1987.

Zbigniew JAKUBIEC i Tadeusz BUCHALCZYK

WYSTĘPOWANIE I LICZEBNOSC NIEDŹWIEDZIA BRUNATNEGO W POLSCE

\section{Streszczenie}

Niedźwiedź brunatny Ursus arctos Linnaeus, 1758 został wytępiony do końca XIX w. na całym niżu Polski i w Sudetach. Jedynie w Karpatach przetrwała niewielka populacja, która także była tępiona. Po drugiej wojnie światowej populacja ta zaczęła się odradzać, wykazując ekspansję terytorialną (Ryc. 1). Aktualnie w 
Karpatach polskich można wydzielić cztery stałe ostoje niedźwiedzia: Beskid Żywiecki i Wysoki, Tatry, Beskid Sądecki i Bieszczady Zachodnie, a na pozostałych terenach stosunkowo często spotyka się osobniki migrujące.

Liczebność niedźwiedzia od 1945 do 1982 roku wzrosła $4-5$ krotnie (Tabela 1 , Ryc. 2). W okresie powojennym szacowano ją na 10-14 osobników, obecnie na 60 -65 sztuk. Zmiany liczebności niedźwiedzia w Tatrach i Bieszczadach (Tabela 3) miały przebieg podobny. W Tatrach po osiągnięciu liczebności 7-10 sztuk utrzymuje się ona na stałym poziomie. W Bieszczadach początkowy powolny wzrost liczebności, uległ wyraźnemu przyspieszeniu w latach siedemdziesiątych i trwa nadal. Wzrost liczebności niedźwiedzia w Polsce jest związany z podobnym wzrostem na Słowacji (Hell, 1981; Macko, 1972; Randik, 1971).

Rozród niedźwiedzia w Polsce jest ograniczony do jego stałych ostoi (Ryc. 1, Tabele 2 i 4), a średni roczny przychówek dla lat 1980-1982 oceniono na 12-14 osobników przy średniej 1,4 młodych od samicy. Przyrost roczny, w wyjątkowo pomyślnym 1982 roku, wynosił 21,9\%. Gawrowanie niedźwiedzia jest również w zasadzie ograniczone do jego stałych ostoi (Ryc. 1), ale pewna liczba zwierząt nie zapada w sen zimowy. W naszych warunkach klimatycznych za osobniki nie zasypiające na zimę (ewentualnie zbudzone) należy uznać te, które chodzą w styczniu i lutym.

W związku z rosnącymi rozmiarami szkód wyłaniają się coraz wyraźniej problemy ochrony niedźwiedzia. Konieczne jest prowadzenie badań w celu określenia jego liczebności i ostoi, odpowiednie przeszkolenie administracji leśnej i ludności oraz wypracowanie generalnej polityki ochrony tego zwierzęcia. 